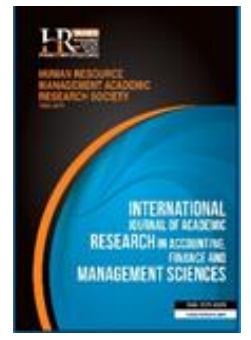

International Journal of Academic Research in Accounting, Finance and Management Sciences

Vol. 8, No.3, July 2018, pp. 128-140

E-ISSN: 2225-8329, P-ISSN: 2308-0337

(C) 2018 HRMARS

www.hrmars.com

To cite this article: De Kai, K. Bin Abd Rahman, I. (2018). The Impact of Financial Indicators towards Stock Returns of Finance Companies Listed on Bursa Malaysia, International Journal of Academic Research in Accounting, Finance and Management Sciences 8(3): 128-140.

\title{
The Impact of Financial Indicators towards Stock Returns of Finance Companies Listed on Bursa Malaysia
}

\begin{abstract}
Khoo De Kai ${ }^{1}$, Ismail Bin Abd Rahman ${ }^{2}$
${ }^{1}$ Azman Hashim International Business School, Universiti Teknologi Malaysia/Asian Institute of Chartered Bankers, Malaysia, ${ }^{1}$ E-mail: kdk620@hotmail.com (Corresponding author) ${ }^{2}$ Azman Hashim International Business School, Universiti Teknologi Malaysia, ${ }^{2}$ E-mail: ismail.utm@gmail.com

Abstract

This research was conducted to examine the relationship between financial indicators which are Earning per Share growth (EPS), Return on Equity growth (ROE) and Dividend per Share growth (DPS) against stock returns of finance companies. The targeted population consists of 31 out of 32 finance companies listed on Bursa Malaysia. Financial indicators and stock returns data are collected within the period from year 2011 to 2016. The data were analyzed by Pearson Correlation method through SPSS software. The finding of the research indicates that there are 5 finance companies show a significant relationship between EPS growth and stock returns, followed by 5 finance companies show a significant relationship between ROE growth and stock return. While 6 finance companies show a significant relationship between DPS growth and stock returns. As a conclusion, even though only minority of public listed finance companies shows a significant relationship between financial indicators and stock returns. However, there are still about half of the finance companies showing strong correlation above 0.5 between financial indicators and stock returns. This has shown that financial indicators still having a certain degree of explanatory power towards stock returns.
\end{abstract}

Key words Earnings per share, Return on Equity, Dividends per Share, Stock Returns, finance companies, Bursa Malaysia

Received: 27 Aug $2018 \quad$ (c) The Authors 2018

Revised: 17 Sept 2018 Published by Human Resource Management Academic Research Society (www.hrmars.com)

Accepted: 28 Sept 2018 This article is published under the Creative Commons Attribution (CC BY 4.0) license. Anyone may Published Online: 08 Oct 2018 reproduce, distribute, translate and create derivative works of this article (for both commercial and noncommercial purposes), subject to full attribution to the original publication and authors. The full terms of this license may be seen at: http://creativecommons.org/licences/by/4.0/legalcode

\section{Introduction}

\subsection{Research Background}

Stock market is known as a place where companies can raise capital while investors can trade stock to seek for profit. Lee (2016) describe that the stock market is a platform where company stocks are listed and traded. The stock market provides liquidity to investors to sell securities easily and quickly and known as the primary channel for public listed companies to raise funds. In Malaysia, the operator of stock exchange is Bursa Malaysia Berhad. The function of Bursa Malaysia is to operate a fully-integrated exchange, offer exchange-related services such as depository services, clearing, trading and settlement (Bursa Malaysia, 2017). In Bursa Malaysia, companies are either listed on the Main Market or ACE Market. To date, there are 901 companies listed on Bursa Malaysia which 32 of them consists of finance companies. The weightage of finance companies in $\mathrm{KLCl}$ (Kuala Lumpur Composite Index) took a significance role which stands approximately 33.15\%. The most recent development in Bursa Malaysia is the establishment of the LEAP market (Leading Entrepreneur Accelerator Platform). This new market aims to enhance the accessibility of Small and Medium Enterprise to raise fund in the stock market. 
The participants of Malaysia stock market can be divided into two categories which are institutional and retail investors. Institutional investors mainly consist of Government Link Investment Companies (GLIC), foreign investment fund and Unit Trusts \& Mutual Fund. While retail investors refer to public who invest in the stock market. Government Link Investment Companies (GLIC) known as the largest participants in Malaysia's stock market. According to Menon and Ng (2013), GLIC in Malaysia consists of Khazanah Nasional Berhad, Kumpulan Wang Simpanan Pekerja (KWSP), Kumpulan Wang Persaraan (KWAP), Permodalan Nasional Berhad (PNB), Lembaga Tabung Angkatan Tentera (LTAT), Menteri Kewangan Diperbadankan (MKD) and Lembaga Tabung Haji (LTH). GLICs are established by the government to undertake strategic investments and manage the funds contributed by specific parties such as employees, government servants, amanah saham unit's holders, government, muslim, armed force and etc. On the other hand, unit trust or mutual funds also known as significant investors in Malaysia stock market after GLIC. As refer to the statistics available in Securities Commission web site (2017), as of July 2017, the total Net Asset Value for unit trust is amounting to RM413.303 billion which translate to $22.37 \%$ of Bursa Malaysia market capitalization. In terms of the retail investors, the participation of retail investors in Malaysia stock market currently stood at 23.3\% (nst.com.my, 2017).

\subsection{Problem Statement}

In recent trends, the stock market has become volatile and sophisticated with the advancement of technology and the introduction of innovative financial products as a result from rapid financial engineering process. Manipulation activities have been increased and this has significantly increased the investment risk in stock market. In fact, there are so many factors such as political stability, economic indicators, financial indicators, reputation of the companies and others that influence stock price movement. However, among the factors that influence stock price movement, there are a group of scholar, which consists of Shaban and Al-Zubi (2014), Arkan (2016) and Dechow et al. (2013) stress that financial indicators are the most crucial criteria to be consider in stock investment. Therefore, the objective of this study is to examine the relationship between earnings per share growth (EPS), Returns on equity growth (ROE), and Dividends per share growth (DPS) against stock returns of finance companies listed on Bursa Malaysia.

\subsection{Research Objective}

i) To examine the relationship between Earnings per share growth (EPS) and stock returns of finance companies listed on Bursa Malaysia.

ii) To examine the relationship between Returns on equity growth (ROE) and stock returns of finance companies listed on Bursa Malaysia.

iii) To examine the relationship between Dividends per share growth (DPS) and stock returns of finance companies listed on Bursa Malaysia.

\section{Literature Review}

\subsection{Theoretical Foundation}

As this study is to study on financial indicators which are consider fundamental of finance companies', value investing theory is applicable. Value investing theory was introduced by Benjamin Graham and David Dodd in the year 1930. Kwag and Lee (2006) state that this theory has served as the first ever rational approach for investment decision. The heart of this theory is to invest in companies trading below its intrinsic value. This can be evaluated through fundamental financial indicators. Besides that, financial model known as the Capital Assets Pricing Model (CAPM) also applicable. CAPM was introduced in the 1960s by William Sharpe, Jack Treynor, John Lintner and Jan Mossin. According to Hasan et al. (2015) The CAPM model state that the systematic risk in connection with stock investment are measurable by beta. Beta is the comparison between the movements between the stocks against the movements for whole stock market. CAPM model explained that the beta is the tool used to explain the stock returns and the stock returns are directly proportional to the beta. As this research has study for the connection between dividend per share and stock returns, a theory called the residual theory of dividends are applicable. According to Gitman (2006), residual theory of dividends explained that the dividend paid by a 
company should be treated as residual (The final amount after undertakes all acceptable investment opportunities). This theory suggests that no dividend is paid if the company equity need exceeds the amount of retained earnings.

\subsection{Literature Review on Variables}

Shabani et al. (2013) state that Earnings per share is one of the most significant financial variables that consider by investor's community. EPS not only provide an indication to investors, but also used to measure the operation efficiency of the companies. Bhatt and Bhatt (2012) view that Earning is a crucial factor that impacts the stock price. Once a company has been successfully generating lucrative earnings, the market will value the companies in higher value that ultimately increase the stock price.

Wong and Ghafar (2015) view that Return on equity is one of the proxy in assessing how effective a company in generating profit over a specific period. Besides that, Satryo et al. (2016) state that profitability or returns are the main reasons why investors want to invest in a company. Therefore, it is crucial to conduct research to determine how the return on equity affects the stock price performance.

Bouteska (2017) express that financial indicator like dividends per share having strong impact on company financial performance. Higher dividends per share declared by companies will attract more investors in investing in the company. Investors always pay a serious attention on how dividend per share affects the stock price performance. Iqbal (2012) state that the companies which pay dividends are those with larger size and in good liquidity position compare with those companies which not pay any dividends.

Schweitzer (1989) explains that movement in stock price will affect the stock returns for particular companies. There are many events can influence the stock returns of a company. Salehi et al. (2011) describe that stock returns is the rate of return for a particular stock in a given period of time.

\subsection{Literature Review on Relationship between Earnings per Share Growth and Stock Returns}

In the country of Iran, as an effort to discover how financial risks intervene the relationship between EPS and stock returns, Babu (2015) has conducted a study by selecting 65 public listed companies in Iran and collect data from 2008 to 2013. He has analyzed the data collected by using Multiple Regression and simple linear regression model. The results of the study show that earnings per share and stock returns are having a significant positive relationship. Further investigation also suggests that solvency and credit risks will negatively affect the connection between earnings per share and stock returns, while liquidity risk does not intervene much on the relationships. Hemadivya and Devi (2013) has done a study to investigate how earning per share and stock price relates to each other by selecting 3 public listed companies in India namely Bharat Heavy electrical limited, Tata Consultancy services, and ONGC. Analysis technique, namely regression, ANOVA and correlation of coefficient have employed to analysis the relationship. The analysis results suggest that there is a positive relationship between EPS and share price of 3 companies in Correlation analysis. While Regression analysis suggests that changes in EPS significantly impact the stock price of Bharat Heavy electrical limited and ONGC but not TCS. In the country of Malaysia, by employed 19 years EPS and stock price data for Public Bank Berhad, Seetharaman and Raj (2011) intend to find out how the earning per share has impacted the stock price performance of Public Bank Berhad. By using analysis techniques which is person correlation method, the outcome of this research shows that a strong correlation between EPS and stock price noted in 19 years period.

\subsection{Literature Review on Relationship between Return on Equity Growth and Stock Returns}

Issah (2015) conclude that ROA, ROE and ROI are significantly connected to share price of public listed financial institutions in Ghana stock exchange. The author has collected data from 2009 to 2013 favoring all listed financial institution in Ghana. The author has chosen ordinary least square method as analysis technique for this research. The results of this study suggest that there is a significant linear connection between share price and variables which are ROA, ROE, and ROI. In addition, the connection between ROE and share price noted in more significant than ROA. In the context of Malaysia, Wong and Ghafar (2015) investigate how variables such as ROA, ROE and ROCE impact the stock returns of Malaysia's plantation companies. The samples of companies in this study consist of 25 plantation companies with data collected from $2004-2008$. The study conducted in the 2 economic periods, which is from 2004 to 2006 
and 2007 to 2008 to test for the resiliency of Malaysian plantation industry. The methodology used in this research is simple linear regression. The results of this research conclude that firstly, return on equity is more useful in forecasting the stock returns. Secondly, during the period before a recession, positive and significant relationship noted between ROA, ROCE, and stock returns. Finally, strong resiliency noted for Malaysian Plantation Industry which not affect much by recession. Rizi and Miri (2016) has taking the effort in conduct a research to examine how return on equity affect the intrinsic value of basic metals industry companies in the context of Tehran Stock exchange. The sample of the study consists of all companies fall under basic metals industries. The period of study is from 2007 to 2011. Person correlation has been used to determine for a relationship. The outcome of the research suggests that significant relationship is noted between return on equity and intrinsic value of stock.

\subsection{Literature Review on Relationship between Dividends per Share Growth and Stock Returns}

In the context of Nepal, Joshi (2012) intend to discover how stock price influence by dividends is by selecting 210 Nepal base public listed companies for year 2010 to 2011. Regression analysis has been used in this research. The results of research show that dividend per share is the strongest factor that move the stock price of both banking and non-banking companies. On the other hand, the author also found that the influence of DPS is stronger than REPS to move the stock price. Last but not least, in Malawi, Gholizadeh et al. (2015) concludes that in the context of Malawi Stock Exchange (MSE), stock price performance significantly affect by dividends. The author has done a research base on 13 Malawi based companies for the period from 2008 to 2014. Correlation analysis has been used to conduct this research. In the context of Iran, Al-Dini et al (2011) has investigated the connection between stock price and variables such as DPS, $\mathrm{P} / \mathrm{E}$ ratio and EPS. The company in this research is Iran Khodro Company. Data are collected in the interval of 3 months in the period of 10 years. This research is done using fuzzy regression technique. The outcome of this research suggests that there is a positive and significant connection between earning per share and stock price of the company. On the other hand, significant negative relationship is noted P/E and DPS of the company.

As a result, based on literature review, the following hypotheses were developed:

$\mathrm{H}_{1}$ : There is a significant relationship between earnings per share growth and finance companies' stock returns.

$\mathrm{H}_{2}$ : There is a significant relationship between return on equity growth and finance companies' stock returns.

$\mathrm{H}_{3}$ : There is a significant relationship between dividends per share growth and finance companies' stock returns.

\subsection{Research Framework}

Independent Variables

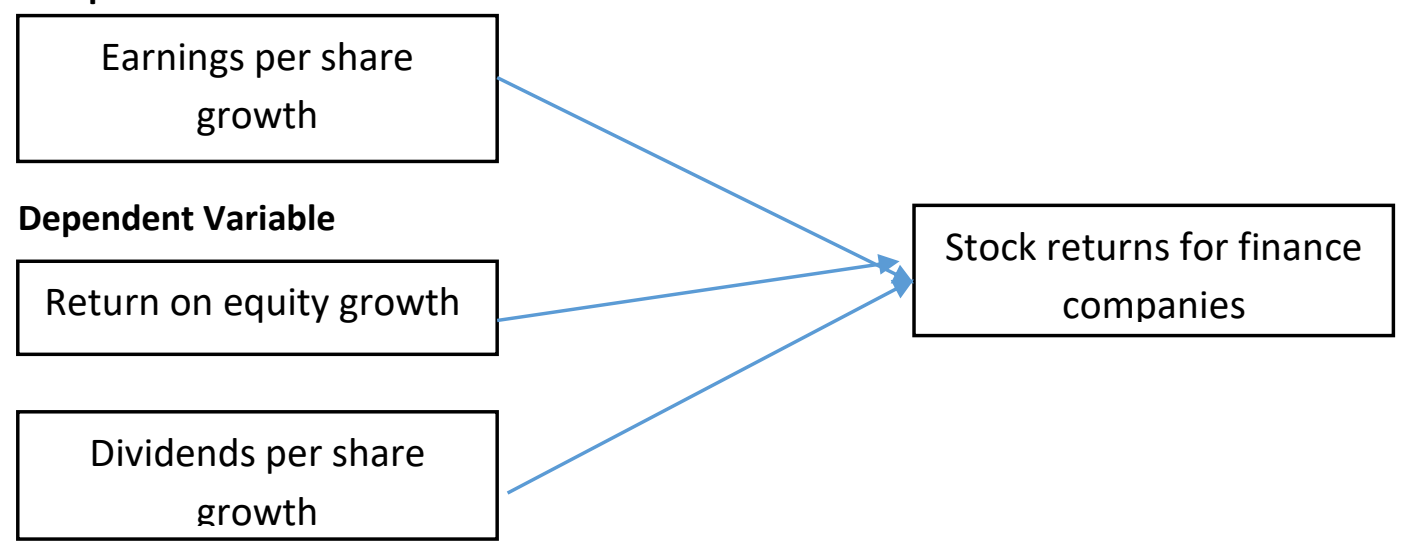




\section{Methodology of research}

\subsection{Variables and Measures}

\subsubsection{Dependent Variable - Stock Returns}

Finance Companies Stock Returns: SR definition is based on Tansuchat et al. (2009) whereby they view that the value of stock prices in a popular equity pricing model theoretically equals the discounted earning expectation of companies in future or in other words future cash flows. Stock returns are the rate of return for a specific stock during certain period.

\subsubsection{Independent Variable - EPS}

Earnings per share growth (EPS): According to Anwaar (2016), Earnings per share known as the most crucial variable used in determining the share's price. It is also an important component to calculate the price-to-earnings valuation ratio, which functions as an indicator of a company's profitability. Placido (2012) calculate the value of earnings per share by below given formula:

Earnings per share $=$ Net income - dividend on preferred stock/Average outstanding Shares

As per stockopedia.com (2018), Earnings per share growth can be explained as the \% of change in earnings per share over the last year to the latest year end. It provides a clear picture of the rate at which a corporation has grown its earnings per share. The formula as below:

[[EPS(Year 2)- EPS(Year 1)]/EPS(Year 1)]*100\%

\subsubsection{Independent Variable - $R O E$}

Return on equity growth (ROE): Based on Anwaar (2016), Return on Equity is an indication on how profitable a company is by comparing its net income to its average shareholders' equity. The return on equity ratio (ROE) measures the earnings of the shareholders for their investment in the company. The ROE determines that how effectively investor's money is being employed. The higher the ratio, the more efficient the company's management is in employing its equity and the better return is provided to the investors. Wang et al., (2013) calculate the value of return on equity by below given formula:

Return on Equity $=$ Net income/Average Shareholders' Equity

In terms of ROE growth, ROE growth can be explained as the \% of change in return on equity over the last year to the latest year end. It provides a clear picture of the rate at which a corporation has grown its return on equity. The formula as below:

[[ROE (Year 2) - ROE (Year 1)]/ROE (Year 1)]*100\%

\subsubsection{Independent Variable - DPS}

Dividends per share growth (DPS): According to Bouteska (2017), he expresses that financial Indicator like dividend per share having strong impact on company financial performance. Higher dividend per share declared by companies will attract more investors in investing in the company. Investors always pay a serious attention on how dividend per share affects the stock price performance. Yanti and Suryanawa (2013) calculate the value of dividend per share by below given formula:

DPS = Total Dividend paid out/Total number of share outstanding

According to morningstar.co.uk (2018) Dividend per share growth is explained as how much the Dividend per share (DPS) has grown when measured against the previous period. The formula as below:

[[DPS (Year 2) - DPS (Year 1)]/DPS (Year 1)]*100\%

\subsection{Population of study}

The population in this research consists of 32 finance companies' listed in Bursa Malaysia as at 31 December 2017. Out of the 32 companies selected, 31 companies are listed on Main Market of Bursa Malaysia and 1 company listed in ACE market. The selection process is based on Bursa Malaysia categorization of company's base on the sector which they fall in. Even though the population of study consists of 32 finance companies', however, this research only focuses on 31 finance companies' with the 
exclusion of Hong Leong Capital Berhad. The trading of Hong Leong Capital Berhad share has been suspended, besides unable to meet public shareholding spread requirement of at least $25 \%$.

\subsection{Data Collection and Analysis technique}

In this research, most data are collected from Yahoo Finance, KLSE Screener, Bursa Malaysia Web Site, i3investors web site and Investment Banks \& Stock Broking Firms Database. Among the data collected are Earnings per share (EPS) of finance companies', Return on Equity (ROE) of finance companies', Dividends per share (DPS) of finance companies' and stock price of finance companies'. The data are collected on time series basis (annual data) from year 2011 to 2016 which comprise of 6 observations for each variable favoring each finance company. The data collected will be converted into growth rate basis (EPS, ROE and DPS) and rate of returns basis (Stock Price). This process is to convert the data into the forms of systematic data. With the assistance of statistical software known as Statistical Package for the Social Sciences (SPSS), the testing for hypothesis can be done. Among the data analysis technique used are, descriptive analysis and correlation analysis. The results from statistical testing will indicate which hypothesis has to be accepted and which one has to be rejected.

\section{Results and Analysis}

\subsection{Correlation between EPS growth and finance companies stock returns}

Table 1. Correlation between EPS growth and finance companies stock returns

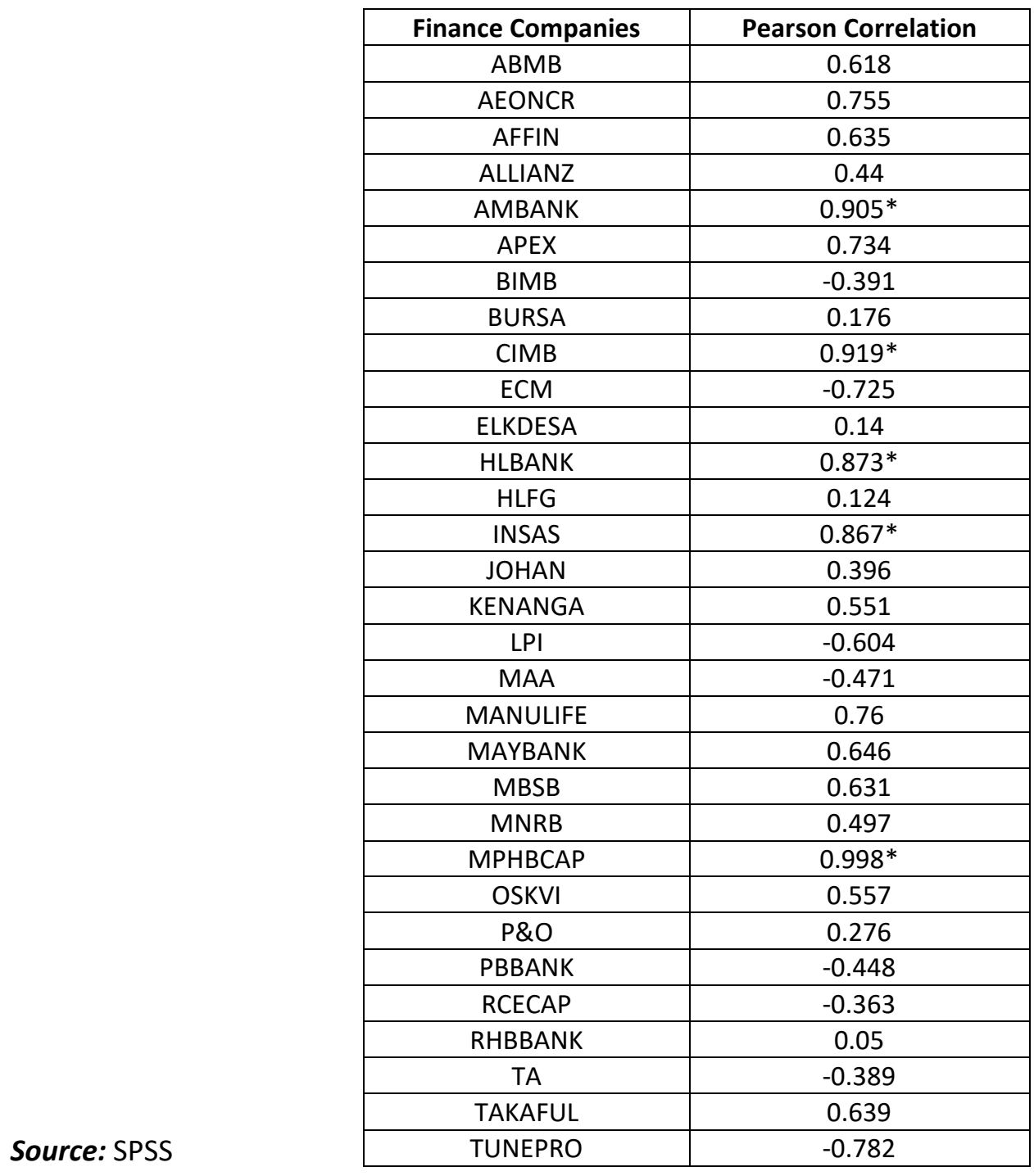

Remarks: *Correlation is significant at the 0.05 level; ${ }^{* *}$ Correlation is significant at the 0.01 level 
From the table, there are 5 out of 31 finance companies (16.12\% of the population) shows a significant relationship between EPS growth and stock returns. Out of the 5 finance companies, 3 companies consist of banks. Banks usually having high standards of corporate governance and it is tightly regulated by Bank Negara Malaysia. Furthermore, the major shareholders of banks usually consist of local and foreign institutional investors who are having high expectation towards their investment returns. Therefore, it can be explained that the stock returns of Banks usually move in tandem with company fundamental which represent by earnings of the companies.

While 10 out of 31 finance companies (32.25\% of the population) shows relatively strong positive correlation above 0.5 for the relationship between EPS and stock returns. From the results, collectively, it shows that the stock returns of $48.37 \%$ of finance companies are either significantly influence by EPS growth or showing a strong correlation with EPS growth. This can be explained as EPS growth can be considered as one of the main financial indicators in predicting the movement of stock returns. Commonly, the increase in EPS will enhance the financial standing of companies' and thereafter improved the company's market value/market capitalization.

On the other hand, there are 8 out of 31 finance companies ( $25.8 \%$ of the population) shows a negative correlation between EPS growth and stock returns. The negative correlation between EPS growth maybe cause by certain scenario whereby the stock returns have lag behind from the reflection of the improvement in financial indicators. Besides that, stock price might rise prior to the announcement of better earning results which cause stock price falls when the actual announcement of companies' results come out.

Last but not least, there are 8 out of 31 finance companies ( $25.8 \%$ of the population) shows relatively weak positive correlation below 0.5 for the relationship between EPS growth and stock returns. This has shown that EPS growth is not the main financial indicator that influences the stock return of those companies.

\subsection{Correlation between ROE growth and finance companies stock returns}

Table 2. Correlation between ROE growth and finance companies stock returns

\begin{tabular}{|c|c|}
\hline Finance Companies & Pearson Correlation \\
\hline$A B M B$ & 0.309 \\
\hline AEONCR & 0.77 \\
\hline AFFIN & 0.576 \\
\hline ALLIANZ & 0.026 \\
\hline AMBANK & $0.985 * *$ \\
\hline APEX & 0.72 \\
\hline BIMB & -0.127 \\
\hline BURSA & -0.49 \\
\hline CIMB & $0.908^{*}$ \\
\hline ECM & -0.679 \\
\hline ELKDESA & $0.953^{*}$ \\
\hline HLBANK & 0.661 \\
\hline HLFG & -0.004 \\
\hline INSAS & 0.617 \\
\hline JOHAN & 0.588 \\
\hline KENANGA & 0.287 \\
\hline LPI & -0.551 \\
\hline MAA & -0.482 \\
\hline MANULIFE & 0.254 \\
\hline MAYBANK & 0.729 \\
\hline MBSB & 0.739 \\
\hline MNRB & 0.556 \\
\hline MPHBCAP & $0.997^{*}$ \\
\hline OSKVI & 0.534 \\
\hline P\&O & 0.268 \\
\hline
\end{tabular}


Source: SPSS

\begin{tabular}{|c|c|}
\hline Finance Companies & Pearson Correlation \\
\hline PBBANK & -0.593 \\
\hline RCECAP & -0.338 \\
\hline RHBBANK & -0.299 \\
\hline TA & -0.547 \\
\hline TAKAFUL & 0.089 \\
\hline TUNEPRO & $0.992^{* *}$ \\
\hline
\end{tabular}

Remarks: *Correlation is significant at the 0.05 level; ${ }^{* *}$ Correlation is significant at the 0.01 level

From the table, there are 5 out of 31 finance companies $(16.12 \%$ of the population) shows a significant relationship between ROE and stock returns. Out of the 5 companies, MPHBCAP, TUNEPRO and ELKDESA was listed since 2013, a relatively short period if compare with other finance companies. Usually, the total equity or shareholder fund for companies which only listed in shorter period is lesser if compare with companies with a longer listing history which having continuous profitability track record. For companies with a shorter listing period, its ROE has a greater space to grow if compared to matured companies. Besides that, the stock returns for newly listed companies also have great potential to grow compare with other companies. Therefore, it can explain that majority of companies' which shows a significance relationship consist of newly listed companies. While 10 out of 31 finance companies (32.26\% of the population) shows a relatively strong correlation above 0.5 for relationship between ROE growth and stock returns. From the results, it shows that the stock returns of $48.38 \%$ of finance companies are either significantly influence by ROE growth or showing strong positive correlation with ROE growth. This can be explained as ROE growth can be considered as one of the main financial indicators in predicting the movement of stock returns. Commonly, the increase in ROE will enhance the attractiveness of a particular stock and thereafter improved the company's market value/market capitalization.

On the other hand, there are 10 out of 31 finance companies (32.26\% of the population) shows a negative correlation between ROE and stock returns. The negative correlation between ROE growth and stock returns maybe caused by certain scenario whereby the stock returns have taken a long time in reflecting the improvement in financial indicators or stock price already rise prior to the announcement of better earning results which cause stock price falls when the actual announcement of companies results come out. Last but not least, there are 6 out of 31 finance companies (19.4\% of the population) shows relatively weak positive correlation below 0.5 for the relationship between ROE growth and stock returns. This has shown that ROE growth is not the main financial indicator that influences the stock return of the companies.

\subsection{Correlation between DPS growth and finance companies stock returns}

Table 3. Correlation between DPS growth and finance companies stock returns

\begin{tabular}{|c|c|}
\hline Finance Companies & Pearson Correlation \\
\hline ABMB & 0.568 \\
\hline AEONCR & -0.523 \\
\hline AFFIN & 0.172 \\
\hline ALLIANZ & -0.791 \\
\hline AMBANK & $0.897^{*}$ \\
\hline APEX & 0.689 \\
\hline BIMB & -0.514 \\
\hline BURSA & -0.730 \\
\hline CIMB & 0.788 \\
\hline ECM & 0.196 \\
\hline ELKDESA & -0.465 \\
\hline HLBANK & $0.926^{*}$ \\
\hline HLFG & -0.011 \\
\hline INSAS & 0.279 \\
\hline
\end{tabular}




\section{Source: SPSS}

\begin{tabular}{|c|c|}
\hline Finance Companies & Pearson Correlation \\
\hline JOHAN & 0.487 \\
\hline KENANGA & 0.656 \\
\hline LPI & -0.348 \\
\hline MAA & -0.637 \\
\hline MANULIFE & -0.775 \\
\hline MAYBANK & 0.502 \\
\hline MBSB & $0.865^{*}$ \\
\hline MNRB & $0.999)^{*}$ \\
\hline MPHBCAP & -0.142 \\
\hline OSKVI & 0.659 \\
\hline P\&O & -0.399 \\
\hline PBBANK & $0.854^{*}$ \\
\hline RCECAP & -0.709 \\
\hline RHBBANK & -0.122 \\
\hline TA & $0.840^{*}$ \\
\hline TAKAFUL & -0.601 \\
\hline TUNEPRO & \\
\hline
\end{tabular}

Remarks: *Correlation is significant at the 0.05 level; ${ }^{* *}$ Correlation is significant at the 0.01 level

From the table, there are 6 out of 31 finance companies (19.35\% of the population) shows a significant relationship between DPS growth and stock returns. This has shown that the stock price performance of HLBANK, AMBANK, RCECAP, MNRB and TAKAFUL are motivated by the dividend distribute by company management. MPHBCAP has shown a negative significant relationship between DPS growth and stock returns. This can be explained as shareholders of MPHBCAP might not agree with the policy in distributing high amount of dividend that might affect the reserve channel for business operation. Therefore, MPHBCAP would be in selling pressure and the stock returns become lower.

While 7 out of 31 finance companies (22.58\% of the population) shows a relatively strong correlation above 0.5 for the relationship between DPS growth and stock returns. From the results, it shows that the stock returns of $41.93 \%$ of finance companies are either significantly influence by DPS growth or showing strong positive correlation with DPS growth. This can be explained as DPS growth can be considered as one of the main financial indicators in predicting the movement of stock returns. Commonly, the increase in DPS will enhance the attractiveness of a particular stock and thereafter improved the company's market value/market capitalization.

On the other hand, there are 13 out of 31 finance companies (41.93\% of the population) shows a negative correlation between DPS growth and stock returns. The negative correlation between DPS growth and stock returns maybe cause by certain scenario whereby the stock returns have taken a long time in reflecting the improvement in financial indicators or stock price already rise prior to the announcement of better dividend distribution which cause stock price falls when the actual announcement of companies results come out. Besides that, the negative relationship between DPS and stock return is due to higher DPS may cause lower cash to be retained in the company for business purpose. This will negatively impact stock returns. Lastly, only 4 out of 31 finance companies (12.90\% of the population) show a weak positive correlation between DPS growth and stock returns. This has shown that DPS growth is not the main financial indicator that influences the stock return of the companies.

The Pearson Correlation result is not applicable for JOHAN whereby JOHAN did not declare any dividend from 2012 to 2016.

\subsection{Hypothesis Testing Results}

From the Pearson Correlation analysis done, the results show that HO (Null Hypothesis) of AMBANK, CIMB, HLBB, INSAS and MPHBCAP was rejected besides significant relationship noted between EPS growth and stock returns for this 5 finance companies. While the HO (Null Hypothesis) for the remaining 26 finance companies was not rejected besides the relationship between EPS growth and stock returns was not 
significant. From the Pearson Correlation analysis done, the results show that HO (Null Hypothesis) of AMBANK, CIMB, ELKDESA, MPHBCAP and TUNEPRO was rejected besides significant relationship noted between ROE growth and stock returns for this 5 finance companies. While the HO (Null Hypothesis) for the remaining 26 finance companies was not rejected besides the relationship between ROE growth and stock returns was not significant. From the Pearson Correlation analysis done, the results show that HO (Null Hypothesis) of AMBANK, HLBANK, MNRB, MPHBCAP, RCECAP and TAKAFUL was rejected besides significant relationship noted between DPS growth and stock returns for this 6 finance companies. While the HO (Null Hypothesis) for the remaining 25 finance companies was not rejected besides the relationship between DPS growth and stock returns was not significant.

\section{Discussions and Recommendations}

\subsection{Research Contribution and Implications}

This study helps investors and fund managers to recognize the financial indicators which affect stock returns of public listed finance companies. From the research findings, investors may take into consideration of EPS growth, ROE growth and DPS growth as factors that influence the finance companies' stock returns. For example, from the results, it shows that the EPS growth, ROE growth and DPS growth of AMBANK significantly correlate with AMBANK stock returns. So, in making a decision in investing in AMBANK, investors may keep track on the financial indicators which are EPS growth, ROE growth and DPS growth. Such action may reduce the risk exposure and maximize the capital gain from the investment.

As most of the public listed companies' vision is to maximize shareholder wealth, since finance companies' stock returns show some form of correlation with financial indicators such as EPS growth, ROE growth and DPS growth. Therefore, the management of finance companies' may design and review strategies to improve the company's financial performance to exhibit better financial indicators. Better financial indicators will ultimately lead to better stock returns which will in turn create value for shareholders. So, in the viewpoint of the finance companies operator, this study will provide a brief idea for them regarding how far their company stock returns have been influence by the movement in financial indicators. Furthermore, it is suggested that they may utilize the finding from this study as a preliminary idea to draw out business plan to improve company financial performance. This action taken by company management that will lead to better stock returns.

In terms of financial market regulators, nowadays, due to advancement in technology, the incidents of stock price manipulation are on an increasing trend with the introduction of new technology such as algorithm trading and etc. Therefore, correlation between financial indicators and stock returns will serve as one of the benchmark or reference to assist financial market regulators to detect the incident of stock price manipulation. The regulators may review those companies which their stock price has risen or fallen far more than the movement in financial indicators and further investigate any possibilities of stock price manipulation.

\subsection{Limitation and Future Research}

Every study has their limitations and there is no perfect study in this world. An insight of a new study and view are observed and the result would be used to improve future study. First of all, the limitation of studies is that the companies selected only limited to finance companies listed on Bursa Malaysia. Thus, it is suggested that future study to be expanded into other categories of companies listed on Bursa Malaysia which are construction, consumer products, hotel, industrial products, mining, plantation, properties, technology, trading/services and etc. This may increase the robustness of the study and the findings might be applicable to the future study in other regional market.

Besides that, as this study only examines the relationship between specific financial indicators such as EPS growth, ROE growth and DPS growth against finance companies stock returns, therefore, it has provided a limited scope to certain selected financial indicators only. Therefore, it is suggested that future study may expand to discover the relationship between other financial indicators which under the categories of liquidity ratio, activity ratio, debt ratio, profitability ratio and common stock ratio against stock returns. This will contribute more towards the literature of discovering the relationship between financial indicators and stock returns. 


\subsection{Conclusions}

As a conclusion, even though based on the research results, only minority of public listed finance companies shows a significant relationship between EPS growth, ROE growth and DPS growth against stock returns. However, the role of financial indicators in predicting stock returns cannot be ignored or underestimated as there are still about half of the finance companies showing strong correlation above 0.5 between financial indicators and stock returns. This has shown that financial indicators still having a certain degree of explanatory power towards stock returns.

\section{Acknowledgement}

I would like to take this opportunity to thanks Dr. Nomahaza Binti Mahadi and Dr. Adriana Mohd Rizal who has given me guidance and advice to complete this paper. Besides that, I would like to thanks my family members who always support me.

\section{References}

1. Al-Dini, S. H. M., Dehavi, H. D., Zarezadeh. E., Armesh. H., Manafi, M. and Zraezadehand, S. (2011). Fitting the Relationship between Financial Variables and Stock Price through Fuzzy Regression Case study: Iran Khodro Company. International Journal of Business and Social Science Vol. 2 No. 11 [Special Issue - June 2011].

2. Anwaar, M. (2016). Impact of Firms' Performance on Stock Returns (Evidence from Listed Companies of FTSE-100 Index London, UK). Global Journal of Management and Business Research: $D$ Accounting and Auditing Volume 16 Issue 1 Version 1.0 Year 2016.

3. Arkan, T. (2016). The Importance of Financial Ratios in Predicting Stock Price Trends: A Case Study in Emerging Markets. Finanse, Rynki Finansowe, Ubezpieczenia nr 1/2016 (79).

4. Babu, M. A. (2015). The effects of financial risks on the relationship between earnings and stock returns. International Journal of Organizational Leadership 4(2015) pp 154-169.

5. Bhatt, P. and Sumangala, J. K. (2012). Impact of Earnings per share on Market Value of an equity share: An Empirical study in Indian Capital Market. Journal of Finance, Accounting and Management, 3(2), pp 1-14, July 2012.

6. Bouteska, A. (2017). The Association between Accounting Earnings, Dividends, Stock Prices and Stock Returns: Value Relevance of Accounting Standards in the Tunisian Stock Market. International Journal of Accounting and Financial Reporting ISSN 2162-3082 2017, Vol. 7, No. 1

7. Bursa Malaysia (2018). List of Companies in Main and ACE market. Available at http://www.bursamalaysia.com/market/listed-companies/list-of-companies/main-market/ http://www.bursamalaysia.com/market/listed-companies/list-of-companies/ace-market/

8. Dechow, P. M., Ak, B. K., Sun, E. Y. and Wang, A. Y. (2013). Do Financial Ratio Models Help Investors Better Predict and Interpret Significant Corporate Events? Available at: http://fbe.unimelb.edu.au/data/assets/pdf file/0004/799591/Dechow - ajms - 20130621.pdf

9. Gholizadeh, M. H., Ramzanpoor, E. and Majanga, B. B. (2015) "The Dividend Effect on Stock PriceAn Empirical Analysis of Malawi Listed Companies. Accounting and Finance Research Vol. 4, No. 3; 2015.

10.Gitman, L. J. (2006) Principles of Managerial Finance. Eleventh Edition, Pearson Addison Wesley.

11.Hasan, S. S., Farooq, S. and Muddassir, M. (2015) Stock Returns Indicators: Debt to Equity, Book to Market, Firm Size and Sales to Price. Journal of Poverty, Investment and Development. ISSN 2422-846X Vol.16, 2015.

12. Hemadivya, K. and Devi, V. R. (2013) A study on relationship between market price \& earnings per share with reference to selected companies. International Journal of Marketing, Financial Services \& Management Research, Vol 2 No 9 Sept 2013.

13.Iqbal, K. (2012) Khan Effect of Dividends on Stock Prices- A Case of Chemical and Pharmaceutical Industry of Pakistan. Proceedings of 2nd International Conference on Business Management (ISBN: 978 969-9368-06-6).

14.Issah, O. (2015) an empirical study of the relationship between profitability ratios and market share prices of publicly traded banking financial institutions in Ghana. International Journal of Economics, Commerce and Management U.K. Vol. III, Issue 12, December 2015. 
15.Joshi, R. (2012) Effects of Dividends on Stock Prices in Nepal. NRB Economic review.

16.Kwag, S. W. and Lee. S. W (2006) Value Investing and the Business Cycle. Journal of Financial Planning. 2006 January Issue - Article 7.

17.Lee, M. P. (2016) Law \& Regulations in Malaysian Banking. Asian Institute of Chartered Bankers. Published by Oxford Fajar Sdn Bhd.

18. Menon, J. and Ng, T. H. (2013) Are Government-Linked Corporations Crowding out Private Investment in Malaysia? April 2013 Working Paper No. 2013/03. Arndt-Corden Department of Economics, Crawford School of Public Policy, ANU College of Asia and the Pacific.

19.Morningstar.co.uk (2018) DPS Growth Available at http://www.morningstar.co.uk/uk/glossary/ 98487/dps-growth.aspx.

20.Nst.com.my (2017). Bursa Malaysia to push retail participation to $25 \%$. Available at : https://www.nst.com.my/business/2017/11/305714/bursa-malaysia-push-retail participation-25

21.Placido M. and Menaje, Jr. (2012). Impact of Selected Financial Variables on Share Price of Publicly Listed Firms in the Philippines. American International Journal of Contemporary Research Vol. 2 No. 9; September 2012.

22.Rizi, M. M. and Miri, S. H. (2016). To Study the Relationship between Return on Equity and the Intrinsic Value of the Stock in Basic Metals Industry Companies Listed in Tehran Stock Exchange (TSE). International Journal of Humanities and Cultural Studies ISSN 2356-5926. Issues 2016.

23.Salehi, M., Talebnia, G., and Ghorbani, B. (2011). A Study of the Relationship Between Liquidity and Stock Returns of Companies Listed in Tehran Stock Exchange. World Applied Sciences Journal 12 (9): 1403-1408, 2011.

24.Satryo, A. G., Rokhmania, N. A. and Diptyana, P. (2016). The influence of profitability ratio, market ratio, and solvency ratio on the share prices of companies listed on LQ 45 Index. The Indonesian Accounting Review Vol. 6, No. 1, January - July 2016, pp. 55-66.

25.Schweitzer, R. (1989) How Do Stock Returns React to Special Events? Business Review July/August 1989. Federal Reserve Bank of Philadelphia.

26.Securities Commission Malaysia (2017). Equities Market Over Statistics. Available at https://www.sc.com.my/data-statistics/equities-market/equities-market-overall-statistics/

27.Seetharaman, A. and Raj, J. R. (2011). An empirical study on the impact of earnings per share on stock prices of a listed bank in Malaysia. The International Journal of applied economics and finance 5(2): pp 114-126/

28.Shaban, O. S. and Al-Zudi, Ziad. (2014). The Role of Financial Indicators in Rationalizing of Investors' Decisions in the Jordanian Stock Exchange Market. ATINER's Conference Paper Series BLE20140901.

29.Shabani, V. and Aghaei, S. M. M., (2013). Investigating the Relationship between Earnings and Stock Prices in Companies Accepted in the Stock Exchange: A Case Study in Iran (2000-2010). European Online Journal of Natural and Social Sciences 2013 Vol.2, No.3 Special Issue on Accounting and Management.

30.Stockopedia (2018). Earnings per Share Growth \%, Last Year Available at: https://www.stockopedia.com/ratios/earnings-per-share-growth-last-year-587/

31.Tansuchat, R., McAleer, M., and Chang, C. (2009). Volatility Spillovers between Returns on Crude Oil Futures and Oil Company Stocks Returns. Available at SSRN: https://ssrn.com/abstract $=1406983$ or http://dx.doi.org/10.2139/ssrn. 1406983.

32.Wang, J., Fu, G. and Luo, C. (2013). Accounting Information and Stock Price Reaction of Listed Companies - Empirical Evidence from 60 Listed Companies in Shanghai Stock Exchange. Journal of Business \& Management Volume 2, Issue 2 (2013), 11-21 ISSN 2291-1995 E-ISSN 2291-2002.

33.Wong, P. H. and Ghafar, M. A. A (2015). The Impact of Accounting Earnings on Stock Returns: The Case of Malaysia's Plantation Industry. International Journal of Business and Management; Vol. 10, No. 4; 2015.

34.Yanti, N. P. N. K and Suryanawa, I. K (2013). Pengaruh Earnings per Share Terhadap Harga Saham Dengan Dividend Per Share Sebagai Variabel Moderasi. E-Jurnal Akuntansi Universitas Udayana 3.2 (2013): pp 212-228. 
LIST OF ABBREVIATIONS

\begin{tabular}{|c|c|c|}
\hline ABMB & - & ALLIANCE BANK MALAYSIA BERHAD \\
\hline AEONCR & - & AEON CREDIT SERVICE (M) BERHAD \\
\hline AFFIN & - & AFFIN BANK BERHAD \\
\hline ALLIANZ & - & ALLIANZ MALAYSIA BERHAD \\
\hline AMBANK & - & AMMB HOLDINGS BERHAD \\
\hline APEX & - & APEX EQUITY HOLDINGS BERHAD \\
\hline BIMB & - & BIMB HOLDINGS BERHAD \\
\hline BURSA & - & BURSA MALAYSIA BERHAD \\
\hline CIMB & - & CIMB GROUP HOLDINGS BERHAD \\
\hline DPS & - & DIVIDEND PER SHARE \\
\hline ECM & - & ECM LIBRA FINANCIAL GROUP BERHAD \\
\hline ELKDESA & - & ELK-DESA RESOURCES BERHAD \\
\hline EPS & - & EARNING PER SHARE \\
\hline GLIC & - & GOVERNMENT LINK INVESTMENT COMPANIES \\
\hline HLBANK & - & HONG LEONG BANK BERHAD \\
\hline HLCAP & - & HONG LEONG CAPITAL BERHAD \\
\hline HLFG & - & HONG LEONG FINANCIAL GROUP BERHAD \\
\hline INSAS & - & INSAS BERHAD \\
\hline JOHAN & - & JOHAN HOLDINGS BERHAD \\
\hline KENANGA & - & KENANGA INVESTMENT BANK BERHAD \\
\hline KWAP & - & KUMPULAN WANG PERSARAAN \\
\hline KWSP & - & KUMPULAN WANG SIMPANAN PEKERJA \\
\hline LPI & - & LPI CAPITAL BHD \\
\hline LTAT & - & LEMBAGA TABUNG ANGKATAN TENTERA \\
\hline LTH & - & LEMBAGA TABUNG HAJI \\
\hline MAA & - & MAA GROUP BERHAD \\
\hline MANULIFE & - & MANULIFE HOLDINGS BERHAD \\
\hline MAYBANK & - & MALAYAN BANKING BERHAD \\
\hline MBSB & - & MALAYSIA BUILDING SOCIETY BERHAD \\
\hline MKD & - & MENTERI KEWANGAN DIPERBADANKAN \\
\hline MNRB & - & MNRB HOLDINGS BERHAD \\
\hline MPHBCAP & - & MPHB CAPITAL BERHAD \\
\hline OSKVI & - & OSK VENTURES INTERNATIONAL BERHAD \\
\hline P\&O & - & PACIFIC \& ORIENT BERHAD \\
\hline PBBANK & - & PUBLIC BANK BERHAD \\
\hline PNB & - & PERMODALAN NASIONAL BERHAD \\
\hline RCECAP & - & RCE CAPITAL BERHAD \\
\hline RHBBANK & - & RHB BANK BERHAD \\
\hline ROE & - & RETURN OF EQUITY \\
\hline SR & - & STOCK RETURNS \\
\hline TA & - & TA ENTERPRISE BERHAD \\
\hline TAKAFUL & - & SYARIKAT TAKAFUL MALAYSIA BERHAD \\
\hline TUNEPRO & - & TUNE PROTECT GROUP BERHAD \\
\hline
\end{tabular}

